\author{
Case Report \\ www.ijrap.net
}

INDRALUPTA (ALOPECIA AREATA) MANAGEMENT BY PRACCHANA AND CUPPING:

\title{
A SUCCESS STORY
}

Imlikumba ${ }^{* 1}$, Mahesh Parappagoudra ${ }^{2}$, Pekyom Ringu ${ }^{3}$

${ }^{1}$ Medical Officer (Ayurveda), North Eastern Institute of Folk Medicine, Pasighat: Arunachal Pradesh, India

${ }^{2}$ Assistant Professor, Department of Panchakarma, Parul Institute of Ayurved, Vadodara, Gujarath, India

${ }^{3}$ Director, North Eastern Institute of Folk Medicine, Pasighat: Arunachal Pradesh, India

Received on: 04/07/19Accepted on: 05/09/19

\author{
*Corresponding author \\ E-mail: imlikumba@gmail.com
}

DOI: 10.7897/2277-4343.1005109

\begin{abstract}
A 35-year-old male patient came to OPD of NEIFM, Pasighat, with the complaints of Hair Loss for 5 years. The patient was taking allopathic treatment, from a Dermatologist but did not get significant relief. He was being prescribed Topical corticosteroids, Intralesional corticosteroids, Minoxidil, Topical immunotherapy and since there was no improvement, he was advised to get hair transplantation done by Tricologist. But as the price of the hair transplantation was very high, he dropped the plan and visited our OPD with the hope, if we could provide any alternative to Hair transplantation through Ayurveda. Examination of the patient Scalp and Hair revealed hair loss in frontal region on the scalp. In consideration with the findings of clinical examination, treatment with Rakta Mokshana (Pracchana \& Cupping) was planned and given which improved the condition of the patient. After the therapy patient felt improvement with hair growth in the affected area and new hairs appearing within just 15 days after therapy.
\end{abstract}

Keywords: Indralupta, Alopecia Areata, Rakta-Mokshana, Pracchana, Cupping, NEIFM.

\section{INTRODUCTION}

There is a great saying that "Invest in your hair, it is the crown that you never take off". Hair is one important part of both male and female look; people usually say, "Before we make eye contact, we make hair contact". So, with these statements we can figure out that hair makes an integral part of one's look. Imagine the horror of losing one's hair at a fast rate it usually brings fear in one's mind. In today's fast-moving world due to pollution, improper diet and regiments, stress and tension, increased industrialization and urbanization, other intrinsic factors and genetic cause etc. there is an increase in hair loss. Ayurved has described hair problems under Kshudra Roga, Shiro Roga as Khalitya, Palitya, Indralupta ${ }^{1}$ etc. Indralupta is a specific condition characterized by hair loss in form of patches in some scalp areas by the vitiation of Tridosha and Rakta Dhatu ${ }^{2}$. Acharya Sushruta states the treatment as Pracchana followed by Lepa or Abhyanga ${ }^{3}$. Pracchana Karma is one type of Shastrakruta Rakta-Mokshana. In this type multiple Shastrapada (pricks) are made by using sharp and pointed instruments like needle or knife over the diseased part. By this procedure the blood oozes out from the local area. Thus, the vitiated Doshas are expelled out and Doshasamyata is achieved and the disease is cured ${ }^{4}$. Cupping is the process of applying cups to various points on the body by removing the air inside the cups to form a vacuum. Cupping is of three types ${ }^{5}$ :

\section{Dry cupping}

This is the process of using a vacuum on different areas of the body in order to gather the blood in that area without incisions (small, light scratches using a sterile surgical blade or disinfected razor).

\section{Dry massage cupping}

This is similar to dry cupping but olive oil is applied to the skin (before applying the cups) in order to allow easy movement of the cups.

\section{Wet cupping}

This is the process of using a vacuum at different points on the body but with incisions in order to remove 'harmful' blood which lies just beneath the surface of the skin.

\section{Case history}

A 35-year-old male patient came to OPD of NEIFM, Pasighat, with the complaints of Hair Loss for 5 years. The patient was taking allopathic treatment, from a Dermatologist but did not get significant relief. $\mathrm{He}$ was being prescribed Topical corticosteroids, Intra-lesion corticosteroids, Minoxidil, Topical immunotherapy and since there was no improvement, he was advised to get hair transplantation done by Trichologist. But as the price of the hair transplantation was very high, he dropped the plan and visited our OPD with the hope, if we could provide any alternative to Hair transplantation through Ayurveda.

Patient consent was taken, and study was carried out as per International conference of Harmonization-Good Clinical Practices Guidelines (ICHGCP) or as per Declaration of Helsinki guidelines.

\section{Chief complaints}

Frontal hair loss on scalp for 5 years 


\section{General examination}

Moderately built with no other systemic illness Systemic

\section{Examination of Scalp and Hair}

- Type- Patchy hair loss.

- Site- Frontal region on scalp

\section{Materials required}

a) Cotton.

b) Spirit.

c) Bhringaraja Leaf Paste.

d) Honey.

e) Insulin Syringe.

f) Surgical Gloves.

g) Cupping Cups.

h) Vacuum Pump.

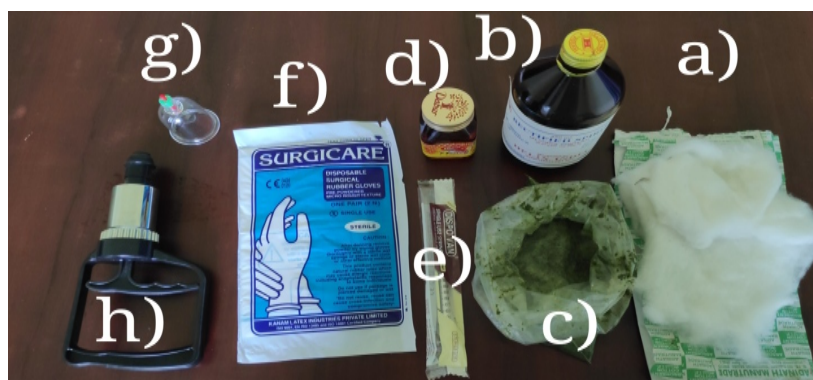

Figure 1: a) Cotton b) Spirit c) Bhringaraja Leaf Paste d) Honey e) Insulin Syringe f) Surgical Gloves g) Cupping Cups h) Vacuum Pump

\section{Purva- karma (Pre-operative procedure)}

The procedure was done in sitting position. Local area is cleaned with Triphala Kashaya/Spirit. Procedure explained to patient in her own language and consent is taken

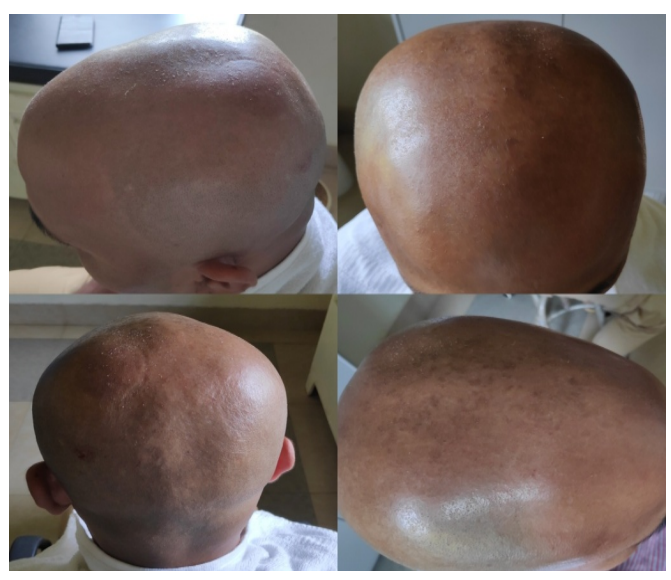

Figure 2: Before Treatment

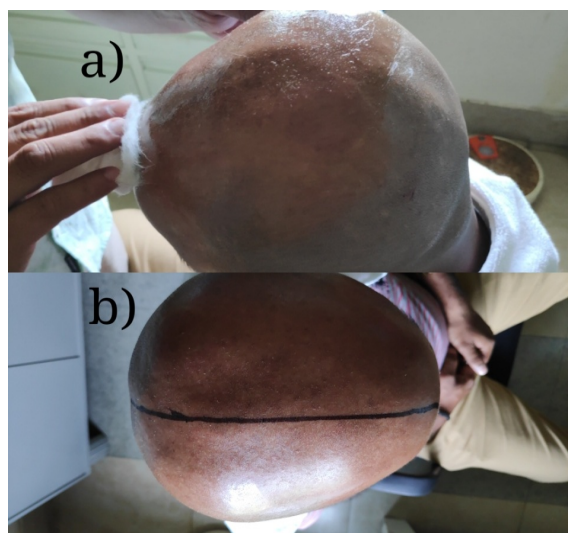

Figure 3: Purva-Karma (Pre-Operative Procedure): a) Cleaning of the affected area. b) Proper Demarcation of the treatment Area

\section{Pradhana-karma (Operative procedure)}

\section{Pracchana}

Insulin syringe is taken and continuously close Rekhapratisaarana was made over the scalp on the affected area. Care is taken so that the depth of these serial incisions should be neither too deep nor too superficial but should be sufficient enough for the blood to ooze out. When the blood started oozing out, before it gets clotted

\section{Cupping}

Cups are applied over affected area and with the help of vacuum pump suction combined with controlled bleeding, in which the skin immediately below the cup is superficially lacerated with very light cuts with insulin syringe, so allowing blood to be withdrawn under the pressure of the cup. The bleeding generally stops automatically as part of the physics response.

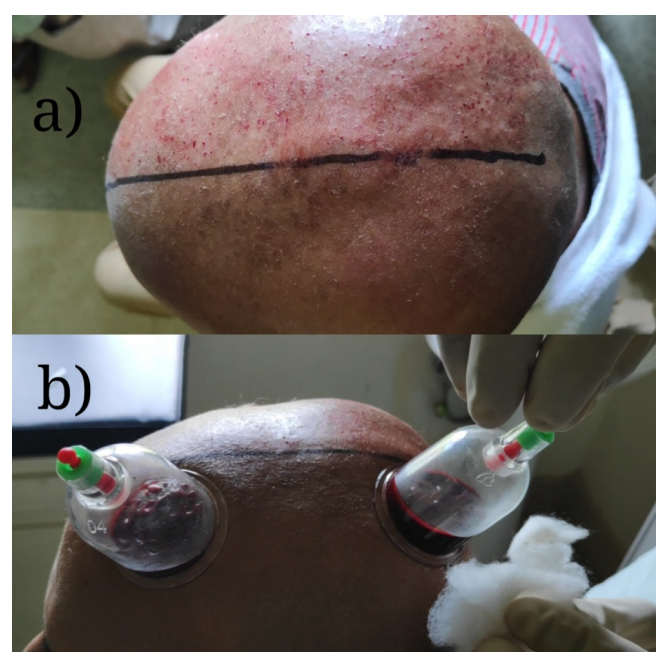

Figure 4: Pradhan-Karma (Operative Procedure): a) Pracchana. b) Cupping 


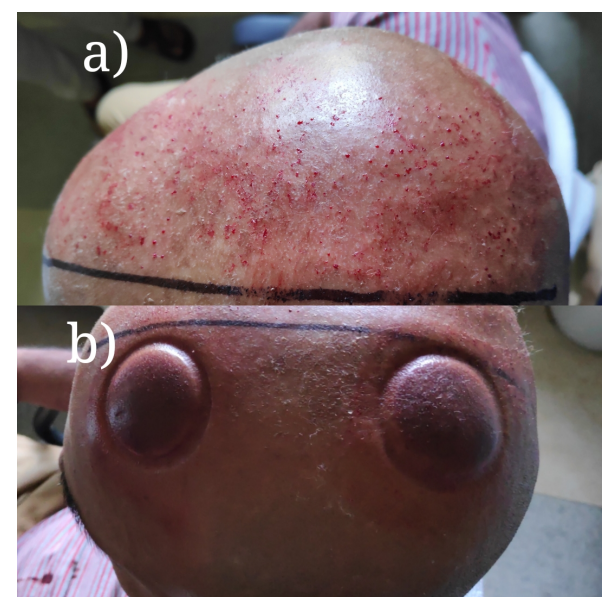

Figure 5: a) After Pracchana. b) After Cupping

\section{Paschata-karma (Post-operative procedure)}

After the procedure patient is advised to take rest then honey is applied over the therapy area and after some time Bhringaraj Patra Lepa is applied and patient is advised to keep it for half an hour and then wash it off with warm water. Patient is advised to apply honey for two days and avoid applying oils to the effected part for some days.

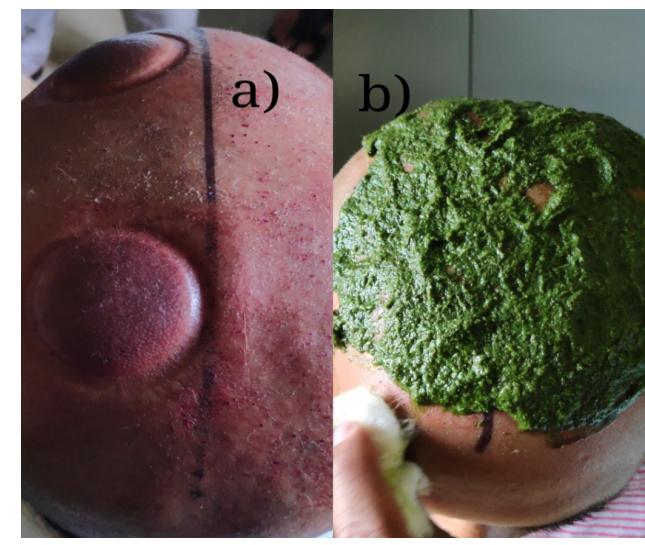

Figure 6: Paschata-Karma (Post-Operative Procedure): a) After Applying Honey. b) After applying Bhringaraja Lepa

\section{Advice after treatment}

Apply Honey, not to use any oils immediately on the day of procedure. Hair should not be combed. Avoid pollution, exposure to sunlight, spicy and junk food.

\section{RESULT AND DISCUSSION}

Pracchana Karma and Cupping both are very simple and result oriented procedure. It is a day care procedure. The localized Raktha along with Dosha will be expelled. Both Pracchana and Cupping releases congestion. The trauma caused by both this procedure will stimulate the accumulation of mast cells at the site and thus helps in improvement of circulation.
There was appreciable hair growth and on bald area of scalp after 15 days of the therapy, hair started growing.

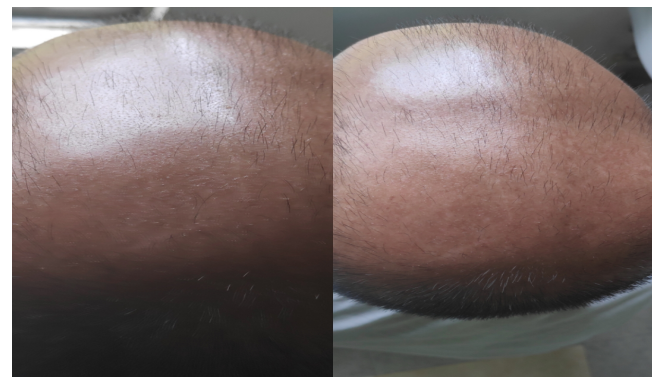

Figure 7: After Treatment (15 Days After)

\section{CONCLUSION}

Hair Transplantation cost is very high but a simple OPD procedure like Pracchana and Cupping can do wonders in the field of Indralupta. Besides this case study is an eye-opener to the Ayurveda fraternity that a simple procedure can bring great results.

\section{ACKNOWLEDGEMENT}

I would like to thank the informant who was ready to undergo the treatment and share the information and also to North Eastern Institute of Folk Medicine, Ministry of AYUSH, Pasighat: Arunachal Pradesh for giving me this opportunity.

\section{REFERENCES}

1. Shastri, K. Sushrut Samhita Nidanasthana Ksuadraroga Nidanasthana chapter 13, verse no. 3 A.M.S, Publication, Varanasi; 2011.p. 365.

2. Shastri, K. Sushrut Samhita Nidanasthana Ksuadraroga Nidanasthana chapter 13, verse no. 33-34 A.M.S, Publication, Varanasi; 2011.p. 368.

3. Shastri, K. Sushrut Samhita Chikitsasthana Ksuadraroga Chikitsasthana chapter 20, verse no. 24-27 A.M.S, Publication, Varanasi; 2011. p. 997.

4. Shastri, K. Sushrut Samhita Sutra sthana chapter 14, verse no. 25 A.M.S, Publication, Varanasi; 2011. p. 997.

5. Cupping Therapy (Al-Hijama): A Cure for Every Disease, Pain and Ailment Posted by Healthy Muslim on Thursday; 2008. visited on 12/6/2019.

6. Harishastri Paradkar (editor), Dr. Anna Moreshwar Kunte and Krishna Ramachandra Navre (collation), commentary: Sarvangasundara of Arunadatta on Ashtangahridayam of Vagbhata, uttarasthanam, chapter 24, verse no. 28. First edition, krishnadas academy; reprint; 1995. p. 862.

\section{Cite this article as:}

Imlikumba et al. Indralupta (Alopecia areata) management by Pracchana and Cupping: A Success Story. Int. J. Res. Ayurveda Pharm. 2019;10(5):76-78 http://dx.doi.org/10.7897/2277$\underline{4343.1005109}$ every effort has been taken to verify the accuracy of the content published in our Journal. IJRAP cannot accept any responsibility or liability for the site content and articles published. The views expressed in articles by our contributing authors are not necessarily those of IJRAP editor or editorial board members. 